\title{
PENGARUH LATIHAN KICKING MOTION MELALUI PENGELOMPOKAN KEKUATAN DAN PANJANG TUNGKAI TERHADAP JAUHNYA TENDANGAN
}

\author{
Ponco Prasetyo $^{1 \bowtie}$, Fajar Ari Widiyatmoko ${ }^{2}$ Setiyawan $^{3}$ \\ Program Studi Pendidikan Jasmani Kesehatan dan Rekreasi, Fakultas Pendidikan Ilmu Pengetahuan \\ Sosial dan Keolahragaan, Universitas PGRI Semarang, \\ poncoco05@gmail.com
}

\section{Article Info}

History Articles

Submitted : 26 Januari 2020

Accepted : 16 April 2020

Published : 14 Juli 2020

\section{Keywords}

Football Away Kick Test; Kicking Motion Exercises; Leg Length; Strength.

\section{Abstrak}

Penelitian ini untuk mengetahui pengaruh gerak menendang bola jauh pada SSB PSW usia 12-14 tahun. Tujuan Penelitian untuk membuktikan pengaruh latihan kicking motion, kekuatan dan panjang tungkai terhadap jauhnya tendangan pada SSB PSW usia 12-14 tahun. Metode pendekatan kuantitatif eksperimen desain. Teknik pengambilan sampel yang terdiri dari 24 peserta di bagi 2 kelompok kontrol dan eksperimen. Analisis data SPSS 22 dengan diuji normalitas, homogenitas, dan anova antar varibel. Berdasarkan hasil uji normalitas, diperoleh hasil data pretest kelas kontrol memiliki nilai Sig. sebesar 0,634, data posttest kelas kontrol memiliki nilai Sig. sebesar 0,695, data pretest kelas eksperimen memiliki nilai Sig. sebesar 0,917 dan data posttest kelas eksperimen memiliki nilai Sig. sebesar 0,824. Semua data memiliki nilai Sig. $>\alpha(0,05)$, maka H0 diterima. Sampel penelitian berarti berasal dari populasi yang berdistribusi normal. 1) Ada perbedaan pengaruh antara pemberian latihan Kicking Motion Kekuatan dengan Panjang Tungkai terhadap jauhnya tendangan bola pada SSB, 2) Ada pengaruh antara kelompok Kekuatan Tinggi dan kelompok Kekuatan Rendah terhadap jarak tendangan pada SSB, 3) Ada pengaruh antara kelompok tungkai panjang dan kelompok tungkai pendek terhadap jarak tendangan pada SSB. Kesimpulan dari penelitian yang dilakukan melakuan latihan Kicking Motion ada pengaruh pada SSB PSW Welahan.

\begin{abstract}
This study is to determine the effect of the motion of kicking to kick a ball far in SSB PSW aged 12-14 years. Research purposes to prove the effect of kicking motion exercises, strength and leg length on kick distance in PSB SSW aged 12-14 years. Quantitative approach of experimental design method. The sampling technique consisted of 24 participants divided into 2 control and experimental groups. Data analysis used SPSS 22 with normality, homogeneity, and ANOVA variables tested. Based on the results of the normality test, the results obtained for the control class pretest data have a Sig. of 0.634, the control class posttest data has a Sig. of 0.695 , the pretest data of the experimental class has a Sig. amounted to 0.917 and the experimental class posttest data had a Sig. amounting to 0.824. The all data has a Sig. $>\alpha$ (0.05), then $\mathrm{HO}$ is accepted. It's mean the study sample comes from a normally distributed population. 1) There is a difference between the influence of giving Kicking Motion Strength and Leg Length exercises to the distance of the ball kick in the SSB, 2) There is an influence between the High Strength group and the Low Strength group on the kick distance on the Jepara SSB, 3) There is an influence between the leg groups length and short limb groups to the kick distance on the Jepara SSB. The conclusions from the research conducted on Kicking Motion exercises have an influence on the SSB PSW Welahan.
\end{abstract}




\section{PENDAHULUAN}

Sepak bola adalah olahraga yang paling populer di dunia. Sepak bola juga merupakan olahraga yang paling di gemari oleh semua kalangan, dari anak-anak hingga orang tua. Sepak bola juga sudah ada sejak dulu. olahraga ini sudah semakin berkembang dari tahun ke tahun. Mulai dari cara bermain, peraturan, baju, sepatu, bola, ukuran lapangan dan yang lainya. Sepak bola juga tidak hanya dinikmati oleh para atlet yang bisa memainkannya, melainkan banyak orang yang tidak bisa bermain bola pun sangat menikmati tentang sepak bola. Sepak bola sekarang tidak hanya sebagai cabang olahraga yang hanya bisa dimiankan oleh orang dewasa saja, namun sekarang sudah banyak anak-anak kecil yang bermain sepak bola, selain itu sudah banyak sekolah sepak bola yang berdiri khusus untuk usia dini.

Pertandingan sepak bola semua pemain mempunyai tujuan yang sama, merebut bola dan mencetak gol. Tak heran jika dalam sepak bola membutuhkan strategi yang dan kerja sama tim yang bagus. Kerja sama itu menciptakan semangat solidaritas antar pemain, bahkan antar tim bertanding. Solidaritas bisa ukuran gawang, jumlah pergantian pemain, dan durasi permainan. (Luxbacher:2011).

Persatuan Sepak bola Seluruh Indonesia (PSSI) sebagai wadah pembinaan sepak bola telah merancangkan dengan membuka Sekolah Sepak Bola (SSB) di usia dini. Menurut KONI (2000:13), bahwa sepak bola dapat dibina umur 12-14 tahun, usia mulai latihan khusus 16-18 tahun dan usia puncak prestasi 23-27 tahun, rata-rata siswa SSB berumur antara 8-15 tahun, dimana pada masa tersebut adalah masa pertumbuhan dan perkembanganan fisik, mental dan emosional anak dalam periode tersebut. Artinya perkembangan atlet usia dini akan lebih berhasil dibandingkan apabila pembinaanya terlambat. Karena di usia 12-14 pemain masih sangat rentang tubuhnya oleh sebab itu peneliti memberi latihan fisik yang sesuai porsinya agar berjalanya usia daya tahan tubuhnya bisa berjalan secara maksimal sesuai porsi yang di berikan

Dalam permainan sepak bola, teknik yang pssing menurut keadaanya dibagi menjadi dua, yakni passing lambung dan passing datar (bawah menyusur tanah) dalam passing bagian tubuh yang banyak memegang peranan penting salah satunya adalah kaki, (Herwin, $2004: 8$ ), Dalam Jurnal Ivan Styawan, menyatakan bahwa menendang bola atas atau melambung sering di lakukan saat terjadi pelanggaran di tenggah lapangan. menendang jauh kearah gawang lawan, karena dengan melalui tendangan yang jauh dan akurat akan mencitakan umpan yang tepat kepada teman, memudahkan permainan, membuahkan kemenangan dan memainkan permainan yang indah.

(Nurcahyo, F .2012) terdapat beberapa bentuk latihan berbeban yang dapat dilakukan dengan target otot tungkai di mana otot tungkai merupakan salah satu otot yang sangat berperan pada saat melakukan gerakan menendang bola. Salah satu bentuk contoh latihan untuk meningkatkan power otot tungkai dapat dilakukan dengan latihan beban kicking motion yaitu latihan di mana seseorang harus mendorong, mengangkat, menarik suatu benda baik itu diri sendiri atau beban dari luar, misalnya: berat badan sendiri, barbell, dumble, jaket berbeban, dan sepatu beban, atau bola medicine.

Kekuatan adalah tenaga kontraksi otot yang dicapai dalam sekali usaha maksimal dilakukan oleh otot atau sekelompok otot untuk mengatasi suatu tahanan. Kekuatan merupakan daya penggerak dan pencegah cedera.selain itu, kekuatan memainkan peranan penting dalam 
komponen- komponen fisik yang lain misalnya power dan kelincahan, kecepatan. Dengan demikian, kekuatan merupakan faktor utama untuk menciptakan prestasi yang optoimal.

Panjang Tungkai Panjang tungkai adalah jarak vertikal antara telapak kaki sampai dengan pangkal paha yang diukur dengan cara berdiri tegak. Panjang tungkai sebagai salah satu anggota gerak bawah memiliki peran penting dalam unjuk kerja olahraga. Sebagai anggota gerak bawah, panjang tungkai berfungsi sebagai penopang gerak anggota tubuh bagian atas, serta penentu gerakan baik dalam berjalan, berlari, melompat maupun menendang.Gerakan memukul dan menyepak adalah gerakan angular, karena gerakan ini didasari dengan gerakan tulang, gerakan ini disertai dengan linier badan agar benda yang disepak rnengenai sasaran (Radioputro, 1973:80).

Berdasarkan penerapan latihan tersebut, disimpulkan bahwa pemberian latihan kicking motion akan membantu kualitas tendangan anakanak SSB Welahan menjadi lebih baik, latihan tersebut mempunyai kegunaan membentuk anak menjadi lebih baik menendang jauh bolanya pada usia 12-14.

\section{METODE}

Penelitian ini dilaksanakan setiap seminggu tiga kali dimulai pada Rabu tanggal 06 November 2019 yang dilakukan Stadion Welahan Jepara jam 15.00 - selesai dengan subjek dalam penelitian ini adalah SSB PSW Usia 12-14 Welahan Jepara.

Menurut Sugiyono (2015:113) Factorial Design yang merupakan modifikasi dari design true experimental yaitu dengan memperhatikan kemungkinan adanya variable moderator yang mempengaruhi perlakuan (variable independen) terhadap hasil (variable dependen)

\section{HASIL DAN PEMBAHASAN}

Data penelitian yang diperoleh berasal dari data pretest dan data posttest Deskripsi data akan menyajikan nilai maksimum, nilai minimum, rata-rata, standar deviasi. Berikut hasil penelitian

1. Uji Normaltas.

Tabel 1. Hasil Uji Normalitas

\begin{tabular}{|c|c|c|c|}
\hline $\begin{array}{l}\text { Variab } \\
\text { el }\end{array}$ & $\begin{array}{l}\text { Kol } \\
\text { mogorof }\end{array}$ & $\begin{array}{l}\text { Asym } \\
\text { p.Sig } \\
\text { (2- } \\
\text { tailed) }\end{array}$ & $\begin{array}{c}\text { K } \\
\text { eterang } \\
\text { an }\end{array}$ \\
\hline $\begin{array}{r}\text { Pretest } \\
\text { kelas control }\end{array}$ & $6^{0,74}$ & 0,634 & ormal \\
\hline $\begin{array}{r}\text { Postes } \\
\text { t kelas control }\end{array}$ & $0^{0,71}$ & 0,695 & ormal \\
\hline $\begin{array}{l}\text { Preste } \\
\text { st kelas } \\
\text { exsperimen }\end{array}$ & $5^{0,55}$ & 0,917 & ormal \\
\hline $\begin{array}{l}\text { Postte } \\
\text { st kelas } \\
\text { exsperimen }\end{array}$ & $9^{0,62}$ & 0,824 & ormal \\
\hline
\end{tabular}

Berdasarkan hasil uji normalitas, diperoleh hasil untuk data pretest kelas kontrol memiliki nilai Sig. sebesar 0,634 , data posttest kelas kontrol memiliki nilai Sig. sebesar 0,695, data pretest kelas eksperimen memiliki nilai Sig. sebesar 0,917 dan data posttest kelas eksperimen memiliki nilai Sig. sebesar 0,824. Karena semua data memiliki nilai Sig. $>\alpha(0,05)$. Maka $\mathrm{HO}$ diterima, yang berarti sampel penelitian berasal dari populasi yang berdistribusi normal (uji prasyarat normalitas terpenuhi).

2. Uji Homogenitas

Tabel 2. Hasil Uji Homogenitas

\begin{tabular}{cccc}
\hline Latihan & $\begin{array}{c}\text { Levene } \\
\text { Stastisca }\end{array}$ & Sig & $\begin{array}{c}\text { Keterang } \\
\text { an }\end{array}$ \\
\hline $\begin{array}{c}\text { Latihan Kicking } \\
\text { Motion Kekuatan } \\
\text { tinggi dan rendah }\end{array}$ & 0.190 & 0,672 & Homogen \\
$\begin{array}{c}\text { Latihan Kicking } \\
\text { Motion Tungaki } \\
\text { panjang dan } \\
\text { pendek }\end{array}$ & 0,698 & 0,423 & Homogen \\
\hline
\end{tabular}


Berdasarkan hasil uji homogenitas, diperoleh nilai Sig. untuk latihan Kicking Motion Kekuatan sebesar 0,672 dan nilai Sig. untuk latihan Kicking Motion Panjang Tungkai sebesar 0,423 . Karena semua variabel memiliki nilai Sig. $>\alpha(0,05)$, maka $\mathrm{H} 0$ diterima yang berarti varians antara kelas kontrol dan kelas eksperimen pada latihan kicking motion, kekuatan dan panjang tungkai terhadap jauhnya tendangan memiliki varians yang homogen (uji prasyarat homogenitas terpenuhi).

\section{Hasil Uji Anova Hipotesis Pertama}

Berdasarkan hasil uji hipotesis, diperoleh nilai Fhitung $=6,216$ dengan Ftabel $(5 \%, \mathrm{df} 1=1, \mathrm{df} 2=11)$ sebesar 4,84 dan nilai Sig. sebesar 0,032. Karena nilai Fhitung $>$ Ftabel dan nilai Sig.<a $(0,05)$. Maka HO ditolak yang berarti Ada perbedaan pengaruh antara pemberian latihan Kicking Motion, Kekuatan dengan Panjang Tungkai terhadap jauhnya tendangan bola pada SSB PSW Jepara. Dimana rata-rata jarak tendangan jauh dengan latihan Kicking Motion Kekuatan sebesar 38,67 dan rata-rata jarak tendangan jauh dengan latihan Kicking Motion Panjang Tungkai sebesar 33,5.

4. Hasil Uji Anova Hipotesis Kedua

Berdasarkan hasil uji hipotesis, diperoleh nilai Fhitung sebesar 19,692 dan Ftabel dengan $\alpha=5 \%$, df1=1,df2=5 sebesar 6,61. Karena nilai Fhitung $>$ Ftabel dan nilai Sig. $<\alpha(0,05)$. Maka $\mathrm{H} 0$ ditolak yang berarti ada pengaruh pemberian latihan Kicking Motion, Kekuatan terhadap jauhnya tendangan. Dimana terdapat perbedaan pengaruh antara kelompok Kekuatan Tinggi dan kelompok Kekuatan Rendah terhadap jarak tendangan pada SSB PSW Jepara. Rata-Rata hasil tendangan jauh untuk kelompok pemain dengan kekuatan tinggi sebesar 41,33, Sedangkan Rata-Rata hasil tendangan jauh untuk kelompok kekuatan rendah sebesar 36 . Sehingga pemain yang memiliki kekuatan tinggi lebih baik daripada pemain yang memiliki kekuatan rendah pada tendangan jauh di sepak bola.

\section{Hasil Uji Anova Hipotesis Ketiga}

Berdasarkan hasil uji hipotesis, dapat diperoleh nilai Fhitung sebesar 13,885 dan Ftabel dengan $\alpha=5 \%$, df1=1,df2=5 sebesar 6,61. Karena nilai Fhitung $>$ Ftabel dan nilai Sig. $<\alpha(0,05)$. Maka HO ditolak yang berarti ada pengaruh pemberian latihan Kicking Motion panjang tungkai terhadap jauhnya tendangan. Dimana terdapat perbedaan pengaruh antara kelompok tungkai panjang dan kelompok tungkai pendek terhadap jarak tendangan pada SSB PSW Jepara. Rata-Rata hasil tendangan jauh untuk kelompok pemain dengan tungkai panjang sebesar 36,67, Sedangkan Rata-Rata hasil tendangan jauh untuk kelompok pemain dengan tungkai pendek sebesar 30,33 . Sehingga pemain yang memiliki tungkai panjang lebih baik daripada pemain yang memiliki tungkai pendek dalam pengaruhnya terhadap tendangan jauh di sepak bola.

Penelitian yang bertujuan untuk mengetahui pengaruh latihan Kicking Motion Kekuatan dan Panjang Tungkai terhadap Jauhnya tendangan sepak bola, dengan sampel penelitian yaitu para pemain SSB PSW Jepara untuk usia 12-14 tahun sebanyak 24 orang, dibagi 2 kelas yaitu kelas kontrol yang tidak diberikan metode latihan kicking motion dan kelas eksperimen yang diberikan latihan kicking motion. Pengambilan data dilakukan dengan tes tendangan jauh selama 3 kali kemudian diambil data untuk jarak tendangan yang terjauh.

Berdasarkan hasil penelitian yang diperoleh ada pengaruh pemberian latihan Kicking Motion Kekuatan terhadap jauhnya tendangan. Dimana rata-rata jauhnya tendangan untuk pemain yang memiliki kekuatan kaki tinggi sebesar 41,33 dan rata-rata jauhnya tendangan 
untuk pemain yang memiliki kekuatan kaki rendah sebesar 36. Sehingga dapat disimpulkan bahwa pemain yang memiliki kekuatan kaki tinggi lebih baik dari pada pemain yang memiliki kekuatan kaki rendah terhadap jauhnya tendangan sepak bola di SSB PSW Jepara. Penelitian ini hampir serupa terdahulu (Amrullah G,W,S. 2017: 1)menyatakan tidak ada kontribusi yang signifikan antara power dan kekuatan otot tungkai dengan ketetapan menendang bola (long pass) pada pemain SSB PSP Jember U- 15. Penelitian ini juga diperkuat dari penelitian terdahulu dari Hasbi, H. dkk. (2015). yang menyatakan bahwa ada pengaruh latihan kekuatan otot tungkai terhadap jauhnya tendangan dalam permainan sepak bola pada Club PS Puma Pombalowo. Selain latihan kicking motion menurut penelitin terdahulu yang serupa (Anshori, H (2016). menyatakan bahwa terdapat pengaruh yang signifikan latihan knee tuck jump dan barrier hops terhadap jauhnya tendangan long pass pada pemain SSB Forza Junior Kaliwungu Kendal Usia $14-15$ tahun. Hal ini berdasarkan hasil penelitian terdahulu yang telah dilakukan (Hafis Gusdiyanto,dkk ) menyatakan pengaruh latihan single multiple jump dan knee tuck jump terhadap keterampilan long pas pada siswa sekolah sepak bola Nusantara Usia 15 - 17 tahun Kota Malang , dua bentuk latihan yang berbeda mempuyai perbedaan, maka diperoleh hasil penelitian latihan sigle multiple jum memberikan pengaruh yang lebih baik dari pada latihan knee tuck jump. Menurut penelitian (Dewi, U. W. K., \& Kurniawati, D. 2016). " menyatakan tidak ada hubungan kekuatan otot tungkai dengan kemampuan menendang bola dalam permainan sepak bola siswa di SMA Negeri 1 Karangtengah Kabupaten Demak.

Latihan kicking motion memberikan pengaruh yang lebih baik dibandingakan dengan siswa yang tidak diberikan latihan. Hal ini disebabkan karena dengan dilakukannya latihan kicking motion pada saat menarik dan menahan beban, otot menerima rangsang yang lebih besar, otot bekerja lebih keras (tahanannya lebih besar) sehingga memberikan pengaruh yang lebih besar terhadap peningkatan daya ledak otot antara kekuatan otot dan kecepatannya dapat dilatih bersama-sama. Setelah dilakukan latihan kicking motion 7 dari 12 siswa merasakan bahwa adanya peningkatan kekuatan menendang. Penelitin ini juga diperkuat (Sanggantara, $Y$ \& Arjuna, F, 2016: 2). menyatankan ada peningkatan rerata jauhnya tendangan lambung setelah diberikan latihan plyometric pemain sepak bola Arkansa Fc. Karena yang serupa dari penelitian Bismar, R,A 2019: 3) menyatakan bahwa seorang pemain sepak bola harus dituntut untuk memiliki daya ledak tungkai yang baik (tinggi) sebagai salah satu factor yang menjamin dalam pencapian hasil optimal, hasil penelitian ini menunjukan bahwa dari hipotesisnya membandingkan bentuk latihanya memberikan kontribusi yang positif dalam mengembangkan teknik dasar melakukan jauhnya tendangan bola.

Berdasarkan hasil penelitian yang diperoleh ada pengaruh pemberian latihan Kicking Motion Panjang Tungkai terhadap jauhnya tendangan. Dimana rata-rata jauhnya tendangan untuk pemain yang memiliki tungkai panjang sebesar 36,67 dan rata-rata jauhnya tendangan untuk pemain yang memiliki tungkai pendek sebesar 30,33. Sehingga dapat disimpulkan bahwa pemain yang memiliki tungkai panjang lebih baik daripada pemain yang memiliki tungkai pendek terhadap jauhnya tendangan sepak bola di SSB PSW Jepara. Hal ini juga diperkuat dari penelitian terdahulu (Nurcahyo, Fathan, 2012: 2) yang menyatakan bahwa ada perbedaan pengaruh tungkai panjang dan tungkai pendek terhadap jauhnya tendangan 
siswa SSB SELABORA FIK UNY KU 15 tahun di Daerah Istimewa Yogyakarta pada tahun 2010. Latihan yang mempengaruhi jauhnya tendangan sangat bervariasi, oleh karena itu peneliti menciptakan latihan baru yang dapat menjadikan atlit bertambah performanya. Peneliti ini serupa oleh (Maulana, A.A 2019) menyatakan ada pengaruh kontribusi kekuatan otot tungkai panjang dan keseimbangan terhadap kemapuan menendang bola pada permainan sepak bola Murid SD Negeri Sungguminasa IV Kabupaten Gowa.

Tungkai pada gerakan menendang bola bertujuan memberikan tekanan dan perkenaan dengan bola serta ayunan sebagai penambahan kekuatan dan jauhnya tendangan bola. Sehingga kerja tungkai seperti tuas. Kerja tungkai dibantu oleh otot-otot tungkai. Otot-otot itu bekerja sehingga mengakibatkan gerakan atau ayunan pada tungkai, sehingga tungkai dapat bekerja untuk menendang bola. Disini tungkai berfungsi untuk perkenaan dengan bola dan memberikan dorongan bantuan dengan kecepatan dari gerak ayunan tungkai itu sendiri. Kecepatan gerakan ayunan tungkai dipengaruhi oleh kerja dari otototot tungkai dan kekuatan dari otot tungkai itu sendiri. Tungkai seseorang merupakan potensi yang besar dalam memperoleh hasil menendang bola jauh yang baik. Karena prinsip kerja dari tungkai adalah seperti tuas, semakin besar bidang tuas/pengungkit maka untuk mengangkat/menghasilkan sesuatu semakin mudah. Begitu pula pada menendang bola makin panjang tungkai seseorang maka untuk mendapatkan hasil yang maksimal semakin mudah. Sehingga panjang tungkai itu sangat mempengaruhi jauhnya tendangan bola. Dengan dimilikinya tungkai yang panjang maka kekuatan yang dihasilkan saat menendang juga akan semakin besar dan akan menghasilkan jarak tendangan yang semakin jauh.
Berdasarkan hasil penelitian tersebut juga di perkuat penelitian terdahulu (Hasbi, 2015: 11) yang menyatakan bAhwa hipotesis yang menyatakan ada pengaruh yang signifikan (berarti), antara latihan kekuatan otot tungkai terhadap jauhnya tendangan dalam permainan sepak bola dapat di terima.

\section{KESIMPULAN DAN REKOMENDASI}

Kesimpulan dalam penelitian ini bahwa latihan kekutan otot tungkai dapat meningkatkan jauhnya tendangan dalam permainan sepak bola Club PS Puma Pombalawo.

Perbedaan pengaruh pemberian latihan Kicking Motion, Kekuatan dan Panjang Tungkai terhadap jauhnya tendangan bola pada SSB PSW Jepara diperoleh nilai Fhitung $=6,216$ dengan Ftabel $(5 \%$,df1 $1=1, \mathrm{df} 2=11)$ sebesar 4,84 dan nilai Sig. sebesar 0,032. Karena nilai Fhitung>Ftabel dan nilai Sig.< $(0,05)$. Maka HO ditolak yang berarti Ada perbedaan pengaruh antara pemberian latihan Kicking Motion, Kekuatan dengan Panjang Tungkai terhadap jauhnya tendangan bola pada SSB PSW Jepara. Dimana rata-rata jarak tendangan jauh dengan latihan Kicking Motion, Kekuatan sebesar 38,67 dan rata-rata jarak tendangan jauh dengan latihan Kicking Motion Panjang Tungkai sebesar 33,5. Setelah diberikan latihan Kicking Motion, Kekuatan dan Panjang Tungkai kriteria hasil tendangan jauh termasuk dalam kategori baik. Dari hasil penelitian yang dilakukan keterbatasan dalam penelitian ini adalah masih kurangnya sarana prasana dalam penelitian. Sarana dan prasaran tersebut meliputi alat yang digunakan saat penelitian kurang begitu banyak jumlahnya. Serta alat ukur yang digunakan untuk mengukur panjang tungkai hanya menggunakan alat sederhana berupa metlin yang seharusnya alat yang digunakan adalah antropometer. Selain itu 
pada penelitian ini latihan yang digunakan untuk meningkatkan jauhnya tendangan hanya menggunakan dua latihan saja. Sehingga untuk penelitian selanjutnya jumlah latihan lebih diperbanyak lagi dan bervariasi.

\section{DAFTAR PUSTAKA}

Agustrianto, Rifki. 2018. Penerapan Model Pembelajaran Team Games Tournament terhadap Hasil Belajar Shooting Bola Basket pada Siswa Kelas VIII SMP Negeri 3 Brebes. Universitas PGRI Semarang: Semarang.

Anshori, H (2016). " Pengaruh Latihan Barrier Hops Terhadap Jauhnya Tendangan Long Pass pada Pemain SSB Forza Junior Kaliwungu- Kendal U 14 - 15 tahun". Journal. Student. UNY.

Amrullah G,W,S. (2017). “ Kontribusi Power dan Kekuatan Otot Tungkai Dengan Jauhnya Tendangan ( Long passing) Dalam Permainan Sepak Bola Pada SSB Jember U-15" . Jurnal Kesehatan Olahraga 5 (1), 2017.

Bismar, R,A (2019). " Pengaruh Latihan Beban Kettler dan Latihan Berbeban Karet Terhadap Jauhnya Tendangan Bola DiTinjau Dari Daya Ledak Tungkai Pada Siswa SMA Negeri 8". Jurnal Pendidikan Kepelatihan Olahraga, 10 (3),2019.

Dewi, U. W. K., \& Kurniawati, D. (2016). “ Hubungan Kekuatan Otot Tungkai Dengan Kemampuan Menendang Bola Dalam Permainan Sepak bola Siswa Di SMA Negeri 1 Karangtengah Demak". Universitas Muhammadiyah Surakarta, (2016).

Nurcahyo, F. (2012). Pengaruh Latihan Kicking Motion terhadap Jauhnya Tendangan Bola dalam Permainan Sepakbola Siswa Ku 15 Tahun di SSB Selabora Fik Uny Pada Tahun 2010. Media IImu Keolahragaan Indonesia, 2(2).

Gusdiyanto, H, dkk.(2016). "Pengaruh Latihan Single Multiple Jump Dan Knee Tuck Jump Terhadap Keterampilan Long Pass Pada Siswa Sekolah epak Bola Nusantara Usia15-17 Tahun Kota Malang". Jurnal Pendidikan Jasmani, 26 (2), 2016.
Hasbi, H. dkk. (2015). Pengaruh Latihan Kekuatan Otot Tungkai Terhadap Jauhnya Tendangan dalam Permainan Sepak bola Pada Club Ps Puma Pombalowo Kecamatan Parigi. Jurnal Pendidikan Jasmani Kesehatan Vol 3(11) 2337- 4535.

Herwin. (2004). Pembelajaran keterampilan sepak bola dasar. Yogyakarta: UNY Press.

KONI. 2000. Garuda Emas Pemanduan dan Pembinaan Bakat Usia Dini. Jakarta: KONI

Luxbacher, Joseph, A. 2011. Sepak Bola. Jakata: Rajawali Pres.

Maulana, A,A. (2019). " Kontribusi Kekuatan Otot Tungkai, Panjang Tungkai dan Keseimbangan Terhadap Kemampuan Menendang Bola Murid SD Negeri Sungguminasa IV Kabupaten Gowa" . Universitas Negeri Makasar, (2019)

Radioputro, 1973. Kinesiologi dan Body Mechanies. Dirjen Pemuda dan Olahraga Depdikbud : Jakarta

Sanggantara, Y \& Arjuna, F, (2016). " Pengaruh Latihan Plyometric Terhadap Hasil Tendangan Bola Lambung Jauh Pada Pemain Sepak bola Arkansaa Fc Magelang" . Journal UNY,Medikora 15 (2), 74-84, 2016

Setiawan, I \& Primasoni, N. (2019). " Pengaruh Latihan Squat Jump dan Lunges Terhadap Tingkat Kemampuan Tendangan Jarak Jauh Pemain Sepak Bola Browidjyo Yogyakarta" . Jurnal Pendidikan Olahraga-S1 8 (6), 2019.

Sugiyono. Metode Penelitian. Bandung: Alfa Beta. 2015: 112. 